\title{
Relationship of transport distance, sex on live weight loss of pigs during transit to slaughter house
}

\author{
PHGJ DeSilva ${ }^{1 *}$, A Kalubowila $^{2}$ \\ *1. Correspondig author: Lecturer, Department of Agricultural Systems, Faculty of Agriculture, Rajarata \\ University, Sri lanka (jayaminiganiesha@yahoo.com) Telephone number- +94 -25-2235102, Fax number- \\ +94-25-2221610, 2. Purchasing \& technical manager, Keells Food Products PLC, 16, Minuwangoda Road, \\ Ekala, Ja-ela, Sri Lanka (anton.kfp@keells.com) \\ Received: 09-09-2011, Accepted : 01-10-2011, Published Online : 13-12-2011 \\ doi: $10.5455 /$ vetworld.2012.150-154
}

\begin{abstract}
The transport distance have a significant impact on the levels of stress burden on animals before slaughter and have an impact on veterinary decision-making about meat edibility and also on the quality of slaughtered animal meat. The objective of the study was to determine live weight, dress weight and body weight loss during transportation of different sex group of pigs into the Slaughtering house. The body weight loss during preslaughter treatment of animals was recorded and carcass value traits were assessed in details. Relationship between pig live weight and dress weight was reported as dress weight $=1.06+0.73$ live weight. There were significant effect of sex and transport distance on live weight at slaughter, carcass weights and dressing percentage $(\mathrm{p}<0.01)$. Pigs given the short transport $(4 \mathrm{Km})$ lost $23.01 \%$ and pigs given the long transport $(90 \mathrm{Km})$ $29.37 \%$ of their initial live weight. Overall, dressing percentage was negatively correlated with the percentage loss of live weight in transport $(P<0.01)$. As conclusion, long transportation of the pigs is a great stress factor and has adverse effects on the live weight of the pigs.
\end{abstract}

Key words: Transport distance, Sex, Live weight loss, Dress weight

\section{To cite this article :}

DeSilva PHGJ , Kalubowila A (2012) Relationship of transport distance, sex on live weight loss of pigs during transit to slaughter house, Vet. World. 5(3): 150-154, doi: 10.5455/vetworld.2012.150-154.

\section{Introduction}

Rearing the pigs at geographically separated areas from slaughter plants is an important issue from sanitary points. Large numbers of pigs, therefore, have to be transported to centralized slaughter houses at the end of the production period. Since, pre-slaughter procedures such as handling to remove from farm, loading and unloading during transportation could be traumatic and stressful for pigs; the maximum care should be taken during that process. According to literature pigs where transported for long distance to the slaughter houses resulting remarkable production loss (Warriss et al., 1983; Bradshaw et al., 1996; Kim, 2004; Lambooy and Engel, 1991).

From the point of view of nutrition and under the pressure of consumers, producers of pork are still forced to deliver pigs with higher meat content of carcass (Cisneros et al., 1996). Lean meat per cent of pig carcass depends on animals' slaughter live weight. Beattie et al ., (1999) emphasized increasing slaughter weight resulted reducing costs per unit weight, increasing carcass yields, and improving meat to bone ratio.

The stress factors during the transportation of pigs could be divided into two main groups as physical and mental (Vecerek et al., 2006; MotaRojas et al., 2006; Becerril-Herrera et al., 2007). The physical factors were titled as temperature, wind, air flow, gas content and oscillation of vehicle used in transit, whilst mental factors were reported as existence of feed and drinking water, anxiety and fear. All these factors increase the secretion of some hormones and enzymes 
resulting remarkable raise at concentration of these metabolites in blood and this process affects the meat quality adversely.

The adverse effects of the trips on pigs are strongly correlated with length and duration of trip and this is directly related with the distance between production house and slaughter plant. This study aims to investigate the possible effects of different transportation period, sex on live weight and dress weight of pigs. Thus to develop regression formula between live weight and dress weight of pigs that could be used to predict dress weight as affected by transportation period and sex.

\section{Materials and Methods}

The study was carried out in Keells Food Products abattoir in Ekala, Ja-ela Sri Lanka during January to February 2011. 539 Land Race $\times$ Large White cross bred samples were randomly selected according to transport distance away from the Keells Food Products abattoir $(<4 \mathrm{Km}$, $10 \mathrm{Km}, 12 \mathrm{Km}, 22 \mathrm{Km}, 30 \mathrm{Km}, 55 \mathrm{Km}, 90 \mathrm{Km}$ ) and different sex category (bacon castrated, gilt, bacon boar) to determine the impact of the transport distance and sex effect on carcass characteristic of pig. The pigs were slaughtered at 28 week of age (corresponding to a carcass weight of approximately $90 \mathrm{~kg}$ ). The deliveries were carried out under similar conditions and similar loading density (20 animals per vehicle). All pigs from each group were processed at the same time. They were weighed immediately before and after transport. Corresponding weight losses during transport were calculated and expressed as a percentage of initial live weight. Then the all pigs were slaughtered after $24 \mathrm{~h}$ rest in bedded lairage space, with full access to food and water. Each pigs were weighed at slaughter, subjected to stunning, allowed for bleeding, scalded at $61{ }^{\circ} \mathrm{C}$ for approximately $5 \mathrm{~min}$, placed in a dehairer, then singeing, eviscerated and the carcasses were individually weighed to obtain the dressed weight.

Since dress value parameters are difficult to obtain based on the live animal basis except after slaughter, therefore reliable and indirect methods for the estimation of dress value using equation is a necessity. The data was then analyzed by regression between live and dress weight using the SPSS 10.0 software. Regression equations for live weight and dress weight data in the transportation period and sex were fitted to the following regression model: linear function of $\mathrm{DW}=\mathrm{B}_{0}+\mathrm{B}_{1}$ LW. If the linear was non significant, then quadratic function was fit.

Statistical analysis: All data were expresses as a percentage of live weight. Effect of live weight, dressed carcass weight on transport distance and sex effect was determined using 77 replicates. Completely randomized design model of the experiment was used and Duncan test was applied to determine the differences among treatments. Further data was then analyzed by regression between live and dress weight using the SPSS 10.0 software. Regression equations for live weight and dress weight data in the different transport distance and sex categories were fitted to the following regression model: linear function of dress weight $=\mathrm{B}_{0}+\beta_{1}$ live weight. If the linear was non significant, then quadratic function was fit.

\section{Results and Discussion}

As live weight at slaughter increased there were significant increases in carcass weight $(\mathrm{p}<0.001)$ and dressing percentage $(\mathrm{p}<0.05)$. Carcass weight is highly correlated with live weight $(r=.93, p=0.00)$. And also, carcass weights is increased linearly $(\mathrm{P}<.001)$ with slaughter live weight (Figure 1). Furthermore, Correa et al., (2006) found as live weight increased there were significant increases could be observed in hot carcass weight and dressing percentage $(P<0.05)$. There were significant effect of sex on live weight at slaughter, carcass weights and dressing percentage $(\mathrm{p}<0.01)$. This increase in carcass yield is consistent with $\mathrm{Gu}$ et al., (1992) and Tess et al., (1986) studies.

Regression equation was developed to calculate the carcass weight by taking live weight. Most suitable Regression model is linear regression model $\left(\mathrm{R}^{2}=86.1 \%\right)$. The reported relationship between pig live weight and dress weight was dress weight $=1.06+0.73$ live weight. As observed by other researchers (Garciamacias et al., 1996; Latorre, et al., 2003), 
Relationship of transport distance, sex on live weight loss of pigs during transit to slaughter house

Table-1: Body weight loss (\% ) of different sex category of pig at different transport period

\begin{tabular}{|c|c|c|c|c|c|c|c|}
\hline \multirow[t]{2}{*}{ Sex } & \multicolumn{7}{|c|}{ Transport distance } \\
\hline & $<4 \mathrm{Km}$ & $10 \mathrm{Km}$ & $12 \mathrm{Km}$ & $22 \mathrm{Km}$ & $30 \mathrm{Km}$ & $55 \mathrm{Km}$ & $90 \mathrm{Km}$ \\
\hline Bacon castrated & $21.75^{\mathrm{a}}$ & $24.37^{\mathrm{a}}$ & $24.85^{a}$ & $26.21^{\mathrm{a}}$ & $26.82^{a}$ & $28.25^{b}$ & $29.37^{b}$ \\
\hline Bacon boar & $22.09^{a}$ & $25.41^{a}$ & $25.83^{a}$ & $26.72^{a}$ & $28.94^{a b}$ & $30.57^{b}$ & $31.37^{b}$ \\
\hline
\end{tabular}

*Differences between means are important in the same row shown by different letters $(p<0.05)$

there were significant increases in dressing yield as live weight at slaughter increased $(\mathrm{P}<0.05)$.

The weight loss of pigs in different transport distances of bacon castrated, gilt, bacon boar during transportation to abattoir were given in Table 1 ( $\mathrm{p}<0.05)$. Pigs generally experience a live weight loss upon leaving the farm until they reach slaughter. Transport losses cause direct financial losses to pig producers and pork processors. As shown in Table-1, the longer the transport distance the percentage of pigs weight lost was higher $(\mathrm{P}<0.01)$. Main lost was found for $90 \mathrm{Km}$ distance (compare with other distances) of bacon boar was recorded as $31.37 \%$, which was considerably higher than the other transport distances $(<0.01)$.

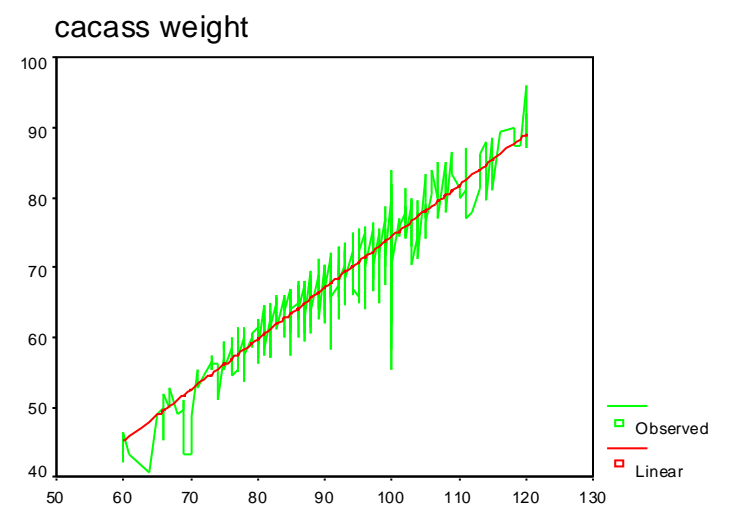

live weight

Figure-1 Relationship of Live Weight and Carcass Weight of pigs

Warris et al., (1990) compared the effect of pre-slaughter transport time on carcass and meat quality and showed that longer transport time of pigs increased live weight loss while resulted in reduced dressing percentage. The sex of the pigs had remarkable effects on body weight loss since weights loss of bacon castrated pigs were found to be lower than bacon boar for both factors Table 1 . Moreover, they showed greater carcass weight loss during $24 \mathrm{~h}$ cooling (35.65\% vs. $26.75 \%$; $\mathrm{P}$ ? 0.01). This emphasizes the profound effect of long-distance transport on final carcass properties.

Greater slaughter weight has the advantage of reducing the overhead costs for producers, slaughterers and processors by increasing carcass yields, improving meat to bone ratio and reducing chilling and processing losses (Ellis and Bertol, 2001). Slaughter weights for hog in the Sri Lanka have been increasing steadily over recent years and currently average approximately $95 \mathrm{~kg}$ for slaughter barrows and gilts. The potential advantages of producing heavier pigs are widely recognized by the slaughtering industry, and this sector would like to increase slaughter weights above current levels. Furthermore, at heavier weights, pork quality was rated higher in terms of juiciness, flavour and tenderness (Piao et al., 2004) and would be attributable to differences in intramuscular fat composition (Hugo et al., 1999).

Transport to the slaughterhouse is a considerable stress burden for pigs. The stress burden level of pigs is especially influenced by the method of treatment of animals at the point of loading, during transport, at the unloading of animals from the transport, transport distance and transportation time. The stress burden of the pigs also increases with the increasing transport distance or transportation time to the slaughter house. Perremans and Geers (1996) emphasise the impact of transportation time on the stress burden of pigs.

The mean dressing percentages from transport period are presented in Table-2. Dressing percentage defined as dividing carcass weight by the live weight and multiplying by 100 . Boar had lower $(P<0.01)$ dressing percentage than gilts 
Relationship of transport distance, sex on live weight loss of pigs during transit to slaughter house

\begin{tabular}{|c|c|c|c|c|c|c|c|}
\hline \multirow[t]{2}{*}{ Sex } & \multicolumn{7}{|c|}{ Transport distance } \\
\hline & $<4 \mathrm{Km}$ & $10 \mathrm{Km}$ & $12 \mathrm{Km}$ & $22 \mathrm{Km}$ & $30 \mathrm{Km}$ & $55 \mathrm{Km}$ & $90 \mathrm{Km}$ \\
\hline $\begin{array}{l}\text { Bacon castrated } \\
\text { Gilt } \\
\text { Bacon boar }\end{array}$ & $\begin{array}{l}74.05^{\mathrm{a}} \\
79.56^{\mathrm{b}} \\
73.05^{\mathrm{a}}\end{array}$ & $\begin{array}{l}77.89^{a} \\
81.13^{b} \\
76.23^{a}\end{array}$ & $\begin{array}{l}77.49^{\mathrm{ab}} \\
80.33^{\mathrm{b}} \\
75.49^{\mathrm{a}}\end{array}$ & $\begin{array}{l}75.64^{\mathrm{ab}} \\
78.89^{\mathrm{b}} \\
73.87^{\mathrm{a}}\end{array}$ & $\begin{array}{l}76.39^{\mathrm{ab}} \\
79.87^{\mathrm{b}} \\
74.39^{\mathrm{a}}\end{array}$ & $\begin{array}{l}78.28^{\mathrm{ab}} \\
81.56^{\mathrm{b}} \\
76.82^{\mathrm{a}}\end{array}$ & $\begin{array}{l}77.18^{\mathrm{ab}} \\
81.43^{\mathrm{b}} \\
75.68^{\mathrm{a}}\end{array}$ \\
\hline
\end{tabular}

*Differences between means are important in the same row shown by different letters $(p<0.05)$

and produced fatter carcasses $(P<0.001)$. Boar produced heavier carcasses than gilts, but dressing percent was greater in gilts than boar, which is in agreement with Langlois and Minvielle (1989) and Ellis et al., (1996). However, neither Cisneros et al., (1996) nor Weatherup et al., (1998) noted an effect of slaughter weight on carcass weight or dressing percent. In agreement with the results of Ellis et al., (1996), Leach et al., (1996), and Hamilton et al., (2000), carcasses from boarwere fatter than carcasses from gilts.

\section{Conclusion}

It is therefore, suggested that the distance between production house and slaughter plant should not exceed $55 \mathrm{~km}$. According to this the decrease of slaughter weight by each $10 \mathrm{~kg}$ leads to increase in lean meat per cent of pig carcass by 1.5 per cent points. As a conclusion, transportation of the pigs is a stress factor and has adverse effects on the live weight of the animals remarkably. The effects of the transportation have a linear relationship with the body weight of the pigs and extensions of transportation distance have severe adverse effects on live weight.

\section{Acknowledgements}

The authors are grateful to the Agriculture Faculty, University of Rajarata and Keells Food Products Company for the facilities and support provided to accomplish this research.

\section{Conflict of interest}

Authors declare that they have no conflict of interest.

\section{References}

1. Beattie, V. E., Weatherup, R. N., Moss, B.W., and Walker, N., (1999) The effect of increasing carcass weight of finishing boars and gilts on joint composition and meat quality. Meat Sci. 52: 205-211.

2. Becerril-Herrera, M., D. Mota-Rojas, I. Guerrero-Legarreta, M. and GonzalezLozano P. S. A., (2007) Effects of additional space during transport on pre-slaughter traits of pigs. J. Boil. Sci., 7: 1112-1120.

3. Bradshaw R. H., Parrott R. F., Forsling M. L., Goode J. A., Lloyd D. M., Rodway R.G., and Broom D.M., (1996) Stress and travel sickness in pigs: Effects of road transport on plasma concentrations of cortisol, betaendorphin and lysine vasopressin. Animal Science, 63, 507-516.

4. Cisneros, F., Ellis, F. K. M., McKeith, J. M., and Fernando. R., (1996) Influence of slaughter weight on growth and carcass characteristics, commercial cutting and curing yields, and meat quality of barrows and gilts from two genotypes. J. Anim. Sci. 74:925-933.

5. Correa J.A., Faucitano L., Laforest J.P., Rivest J., Marcoux M., and Gariepy C., (2006) Effects of slaughter weight on carcass composition and meat quality in pigs of two different growth rates Meat Science, 72, 1, 91-99.

6. Ellis, M., and Bertol, T. M., (2001) Effects of slaughter weight on pork and fat quality. Proceedings of the 2nd international virtual conference on pork quality, Concordia, Brazil, 213-224.

7. Ellis, M., A. J. Webb, P. Avery, J., and Brown. I., (1996) The influence of terminal sire genotype, sex, slaughter weight,feeding regime and slaughter-house on growth performance and carcass and meat quality in pigs and on the organoleptic properties of fresh pork. Anim. Sci. 62:521-530.

8. Garciamacias, J. A., Gispert, M., Oliver, M. A., Diestre, A., Alonso, P., Munoz-Luna, A., Siggens, K., and Cuthbert-Heavens, D., 
(1996) The effects of cross, slaughter weight and halothane genotype on leanness and meat and fat quality in pig carcasses. Animal Science, 63, 487-496.

9. Gu, Y., Schinckel, A. P., and Martin. T. G., (1992) Growth, development, and carcass composition in five genotypes of swine. J. Anim. Sci. 70:1719.

10. Hamilton, D. N., M., Ellis, K. D., Miller, F. McKeith, K., and Parret. D. F., (2000) The effect of the Halothane and Rendement Napole genes on carcass and meat quality characteristics of pigs. J. Anim. Sci. 78: 2862-2867.

11. Hugo, A., Osthoff, G., and Jooste, P. J., (1999) Effect of slaughter weight on the intramuscular fat composition of pigs. Proceedings of the 45th international congress of meat science and technology, Yokohama, Japan, 1-6 August 1999, 496-497.

12. Kim D. H., Woo J. H., and Lee C. Y., (2004) Effects of stocking density and transportation time of market pigs on their behaviour, plasma concentrations of glucose and stress associated enzymes and carcass quality. Asian-Australasian Journal of Animal Sciences, 17, 116-121.

13. Lambooy E., and Engel B., (1991) Transport of slaughter pigs by truck over a long-distance - some aspects of loading density and ventilation. Livestock Production Science, 28, 163-174.

14. Langlois, A., and Minvielle. F., (1989) Comparisons of three-way and backcross swine: Growth performance and commercial assessment of the carcass. J. Anim. Sci. 67:2018-2024.

15. Latorre, M. A., Lazaro, R., Gracia, M. I., Nieto, M., and Mateos, G. G., (2003) Effect of sex and terminal sire genotype on performance, carcass characteristics, and meat quality of pigs slaughtered at $117 \mathrm{~kg}$ body weight. Meat Science, 65, 1369-1377.

16. Latorre, M.A., Lhzaro, R., Valencia, D.G., Medel, P., and Mateos, G.G., (2004) The effects of sex and slaughter weight on the growth performance, carcass traits, and meat quality characteristics of heavy pigs. $J$.
Anim. Sci. 82: 526533.

17. Leach, L. M., Ellis, M., Sutton, D. S., Mc Keith, F. K., and Wilson. E. R., (1996) The growth performance, carcass characteristics, and meat quality of Halothane carrier and negative pigs. J. Anim. Sci. 74:934-943.

18. Mota, R.D., Becerril, M., Lemus, C., Snchez P., and Gonzlez M., (2006) Effects of mid-summer transport duration on preand post-slaughter performance and pork quality in Mexico. Meat Sci., 73: 404-412.

19. Perremans S., and Geers R., (1996) Effect of transport on some welfare characteristics of slaughter pigs. Flemish Veterinary Journal, 65, 310-317.

20. Piao, J. R., Tian, J. Z., Kim, B. G., Choi, Y. I., Kim, Y. Y., and Han, I. K., (2004) Effects of sex and market weight on growth performance carcass characteristics and pork quality of market hogs, Asian-Australasian Journal of Animal Sciences, 10, 1452-1458.

21. Tess, M. W., Dickerson, G. E., Nienaber, J. A., and Ferrell. C. L., (1986) Growth, development, and body composition in three genetic stocks of swine, J. Anim. Sci. 62:968.

22. Vecerek V., Malena M., Malena M., Voslarova E., and Chloupek P., (2006) The impact of the transport distance and season on losses of fattened pigs during transport to the slaughterhouse in the Czech Republic in the period from 1997 to 2004, Veterinarni Medicina, 51, 1:21-28.

23. Warris P. D., Brown S. N., Bevis E. A., and Kestin S. C., (1990) The influence of preslaughter transport and lairage on meat quality in pigs of two genotypes, Animal Production 50, 165-172.

24. Warriss P. D., Dudley C. P., and Brown S. N., (1983) Reduction in Carcass Yield in Transported Pigs, J Sci. Food Agri. 34, 351356.

25. Weatherup, R. N., Veattie, V. E., Moss, B. W., Kilpatrick, D. J., and Walker. N., (1998) The effect of increasing slaughter weight on the production performance and meat quality of finishing pigs, Anim. Sci. 67: 591-600. 